\title{
The Use of a Six-Level Model of Business Development in Practice
}

\author{
Branislav Micieta ${ }^{1}$, Vladimira Binasova ${ }^{1,}{ }^{,}$, Marta Kasajova $^{1}$, Gabriela Gabajova ${ }^{1}$ and \\ Beata Furmannova ${ }^{1}$ \\ ${ }^{1}$ University of Zilina, Faculty of Mechanical Engineering, Department of Industrial Engineering, \\ Univerzitna 1, 01026 Zilina, Slovakia
}

\begin{abstract}
.
Research background: Globalization processes bring many advantages and disadvantages within the economic, political, social as well as ecological environment. The economic advantages come mainly from the possibility of finding cheaper production inputs, which results in better competitiveness of companies and the supply of goods at lower prices.

Purpose of the article: In order to obtain a comprehensive view of the company's development, it is appropriate to use a model of six levels of company development, which allows for a good structuring of general and specific conditions of company development.

Methods: The paper deals with the analysis of individual levels of business development, which are described in more detail in the introduction, which was carried out through a questionnaire, observation, personal interviews, etc. It also contains suggestions for improvements where industrial engineering methods are used. The benefits of the following study may include the analysis of individual levels in practice, the design of the use of a six-level model at various levels of business development, increasing the abilities and skills of individual operators by introducing a substitution matrix that will include individual operators in the cells.

Findings \& Value added: Another benefit is an increase in motivation for employees, which will affect the work performance and quality of finished products using a new incentive system with various rewards. The information obtained about customers through the implementation of the CRM system provides all the information from the beginning of communication with the customers themselves and improved the clarity of the activities of individual employees.
\end{abstract}

Keywords: six-level model; business development; globalization; sustainability.

JEL Classification: $J 24 ; O 15 ; I 25$

\footnotetext{
* Corresponding author: vladimira.binasova@,fstroj.uniza.sk
} 


\section{Introduction}

To obtain a comprehensive view of the development of the company, it is appropriate to use the model of six levels of development of the company shown in Fig.1. This model makes it possible to structure the general and specific conditions of the company's development well. The corporate culture, which is a manifestation of the thinking and behaviour of employees, also reflects their approach to change and the ability to actively participate in innovation processes.

Corporate culture is the highest level in the business development model. It is built on a long-term basis on the basis of cooperation and mutual relations between the company's employees and between the company and its partners. It is a reflection of ideas values and approaches generally shared, maintained in the company for a long time. It is possible to concretize the idea of corporate culture by describing the individual elements as follows:

- ideas about one's own work, its meaning, the company's success, remuneration, etc.,

- approaches to work, to co-workers, to company goals, to innovations, to conflicts,

- values recognized, respected and developed.

Strategic level focuses on the development of strategies aimed at building a top company. Also focuses on certain advantages that it can provide over competing companies. [1]

The socio-psychological level concerns the development of workers and the building of interpersonal relationships. The development of this level is key to the management of innovation, as creative individuals are the source of new ideas and through the cooperation of people, new ideas can also be realized. Society and individuals (the human factor) as bearers of knowledge, skills and the ability to apply them in experimentation are what allow us to push the boundaries of what is possible. However, it is indisputable that in order to acquire, retain and use the necessary intellectual capital, it is necessary to have a suitable system of motivation and sufficient resources.

The economic and financial level is responsible for obtaining and effectively maintaining all types of resources. The question of the necessity of this level is not often questioned. Rather, we encounter a situation where the view is enormously focused on raising as much money as possible. Procurement of qualified workers, technologies and material equipment of production systems is always associated with the need to secure financial resources.

The company can secure financial resources either through a loan, its own funds or by accepting a partner, thus increasing the share capital. Financial the company's situation can be ascertained through the economic result. Economic the result shows the difference between costs and revenues.

Information and material flows form the basis of the pyramid in the company. With their support, the necessary production processes are implemented. At present, various information systems are known which provide companies with an overview of all production processes.

The level of processes and material flow - the material flow can be understood as the organized movement of material in the production and non-production process. The movement of material from the point of view of logistics can be divided into active and passive elements. Among the active elements we can include transport and handling stands, which have energy that serves them to perform movement. Passive elements can include material that is the result of the movement of the active element. The result of active and passive elements is a material flow that displays the material from the material input to the output of the finished products.

An innovative enterprise is one that has implemented at least one technical new or significantly improved product during a given period. These are companies that are 
constantly dedicated to innovation; their corporate strategy is based on the creativity of employees and focus on increasing value for the customer. [2-10]

We can define the innovative ability of a company as a set of preconditions for the emergence of innovation. Innovation performance can be simply defined as the ability to turn innovative inputs into outputs. [11-14] Innovation activities in a company can be influenced by many factors. In an innovative company, an important work environment that thrives on teamwork and innovation is important. Also important is the culture, atmosphere or character, the environment that wishes creativity in the company. Participation should be open and encouraged in the business environment employees. [15-19]

\section{The purpose of case study and methods}

The selected company is engaged in the production of fuel pumps for the automotive industry. At level of corporate culture (Fig. 1), it will analyze the corporate culture in the selected company.

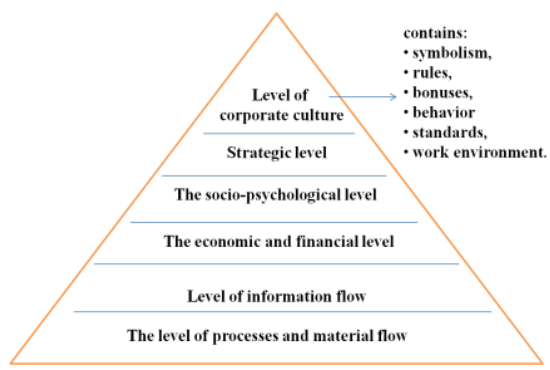

Fig. 1. Six levels of business development - level of corporate culture

The survey showed that employees in the company would like to improve motivation, salaries and bonuses for all employees to achieve higher performance. At present, employees are not entirely satisfied with their remuneration for the work performed. They would also like to improve communication and support from superiors in promoting new suggestions for improvement. Improving their skills through training according to which section the individual employees are located in. Improving the environment and complying with the rules resulting from internal directives.

At the strategic level (Fig. 2), in addition to the vision and mission, staff training, an increase in the number of ispections and monitored indicators were analyzed.

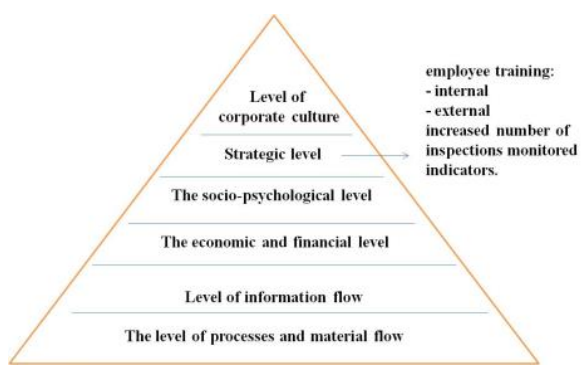

Fig. 2. Six levels of business development - strategic level 
At the socio-psychological level (Fig. 3), the motivational assessment for operators will be analyzed. We will also focus on the benefits that the company provides to its employees. The next step will be the analysis of job positions of individual operators during a work shift.

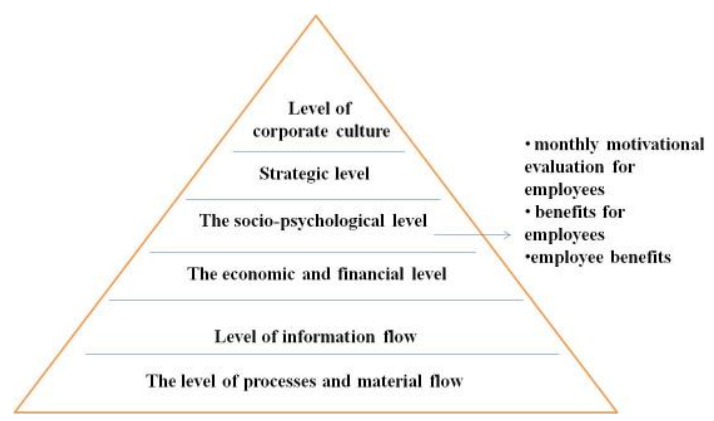

Fig. 3. Six levels of business development - the socio-psychological level

The company has at its disposal all documents from the payment of the necessary resources, such as consumption of energy, water, gas through paid invoices. Information on the financial situation is obtained from paid invoices, which are posted. After processing all data, the company will prepare an annual report for the accounting period (Fig. 4).

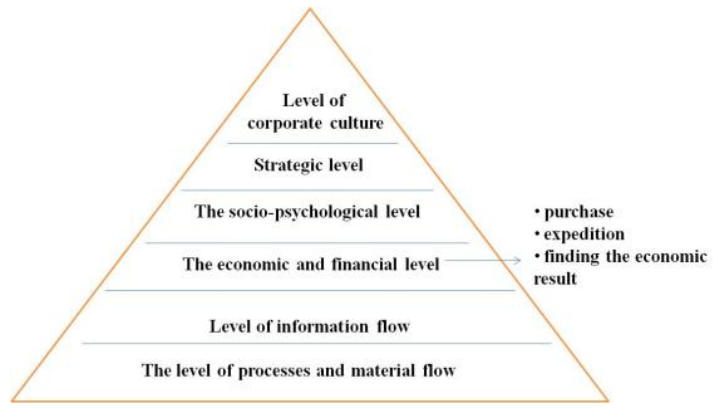

Fig. 4. Six levels of business development - the economic and financial level.

The level of information flow (Fig. 5) is devoted to the analysis of information flow. We will find out how the attendance of employees is registered, they register components, they register finished products. How the information system works directly in the company.

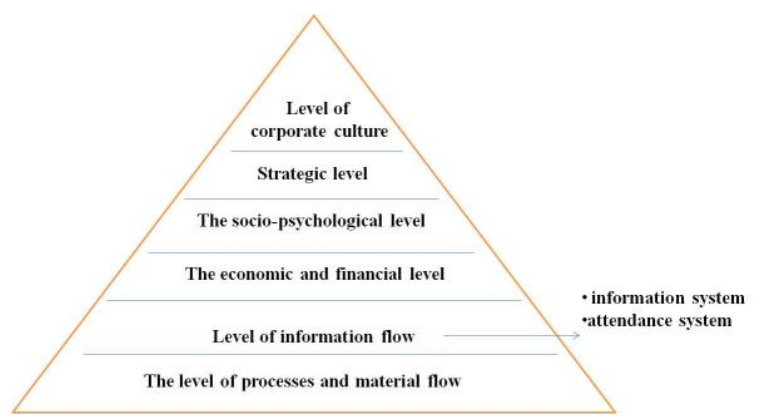

Fig. 5. Six levels of business development - Level od information flow. 
The level of processes and material flow (Fig. 6) begins by securing the materials that are imported in the containers. Shipping takes about 6 weeks to transport the materials. As additional transport, they use trains, air transport and then trucks, which bring it directly to the assembly plant. Imported materials are stored.

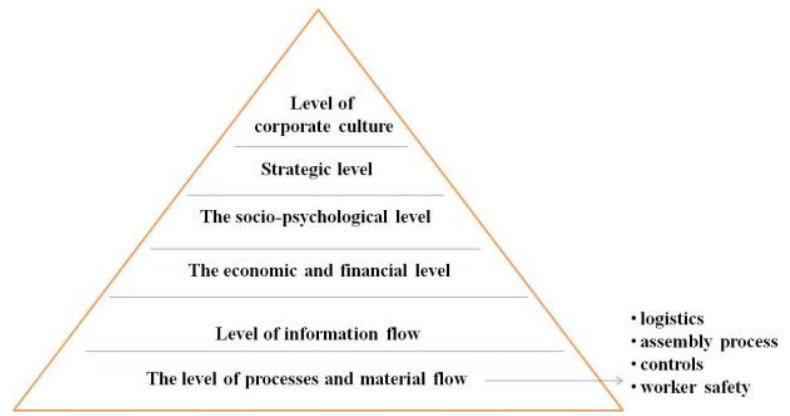

Fig. 6. Six levels of business development - The level of processes and material flow.

\section{Results and discussion}

Proposal no. 1 - to improve the work performance and thus the quality of finished products, a proposal was created. "Loyalty program", which will consist of individual activities performed by operators, warehouse keepers, suppliers and THP workers in their work. For a job well done, they can get credit for which they can then choose a reward. Remuneration consists of various vouchers that employees can use for their own needs. The data obtained for the evaluation will be obtained from the attendance of employees. Adherence to $5 \mathrm{~S}$ is obtained from the team leader themselves, who are responsible for the order of the cells in charge.

Proposal no. 2 - by introducing a substitutability matrix, we will increase the abilities and skills of individual operators and remove monotony. From a stable job position, operators will take turns every day, performing different work activities depending on the activity for which they were trained. If any operator knows all the work and will have longterm experience in which case they can be designated as a team leader. The substitutability matrix will be placed on the boards next to the individual production cells.

Proposal no. 3 - to achieve a successful business, it is necessary to innovate all information systems. We will focus on a system that manages and maintains customer relationships. From a wide range of information systems, we decided to use FLOWii.

Practical benefits:

- elaboration of analysis of individual levels in practice,

- elaboration of a proposal for the use of a six-level model at individual levels of company development,

- increasing the abilities and skills of individual operators by introducing substitutability matrices, which will include individual operators on the cell and the work operations that are part of the assembly cell. It will be marked for each operator which assembly operations he controls,

- increasing motivation for employees, which will affect the work performance and quality of finished products using a new incentive system with various rewards, which will try to better motivate employees,

- increasing production and gaining new customers, through the introduction of a third work shift and an increased number of employees, 
- increased information about customers through the implementation of the Flowii CRM system, which will provide all the information from the beginning of communication with the customers themselves,

- improving the clarity of the activities of individual employees through the Flowii system, which will contain a calendar in which all the plans of individual THP employees will be recorded.

\section{Conclusions}

The main goal of the case study was to use a six-level model of business development. The use of the six-level model took place in a selected company. In the first chapter, the theoretical foundations in the solved area were defined. The second chapter is devoted to methods and analysis of the current situation in the selected company. The information obtained is divided between six levels. At the highest level, I focused on corporate culture, in this case, I focused on the visible features of the company, such as. logo which I consider to be the main identification of the company. At this level, I conducted a survey among THP employees in the form of a questionnaire, which was evaluated graphically and evaluated the current situation of the company. In the second level, I focused on a strategy that is very important. They are mentioned competitive advantages. I consider the increased number of inspections if there is self-inspection and continuous inspection among the competitive advantages. Another advantage is the internal training of employees, which I consider to be the know-how of the company. The third is the socio - psychological level. At this level, I focused on employees and their motivation and benefits that they have within the company.

The fourth is the economic - financial level. It provides basic information about the resources that are available located in the company is a qualified staff, using modern technology. We also focused on financial resources in society. The fifth level focuses on the information flows that take place in society. It is one of the most important without them, society could not function. We focused on systems that perform employee attendance as well as input components and finished products. In the sixth level, we focused on the analysis of material flow. The basis of the material flow is the provision of input components for which input control is important. To ensure a smooth material flow, we focused on employee safety. For the analysis of current production costs, we chose aggregated plans. After completing the analysis, I created a summary of certain problems that I would like to solve.

In the third chapter, I focused on the design of the use of a six-level model in the company. Suggestions for improvement took place at various levels. The first proposal is an improved motivation system for employees was created loyalty program a proposal to improve is to increase the abilities and skills of individual operators within the substitutability matrix.

The third proposal is to implement the Flowii CRM system it manages customer relations and the company provides detailed information on activities, records, invoicing whether the invoice is paid or not. It will also alert employees to individual business meetings, and allow for mass emailing. If the company wants to become one of the top companies in Slovakia, it must ensure development at all six levels, which are very important for the company.

„This work was supported by the Slovak Research and Development Agency under the contract No. APVV-19-0305.“ 


\section{References}

1. Turekova H., Micieta, B. (2010). Inovačný manažment. Žilina: Vydala Žilinská univerzita v Žiline, ISBN 978-80-89478-02-6.

2. Currie, D., Gormley, T., Roche, B., Teague, P. (2017). The Management of Workplace Conflict: Contrasting Pathways in the HRM Literature. International Journal of Management Reviews, 19(4), 492-509.

3. Kohlhoffer-Mizser, C. (2019). Conflict management-resolution based on trust? Ekonomicko-manazerske spektrum, 13(1), 72-82.

4. Belas, J., Smrcka, L., Gavurova, B., Dvorsky, J. (2018). The Impact of Social and Economic Factors in the Credit Risk Management of SME. Technological and Economic Development of Economy, 24(3), 1215-1230.

5. Meyers, T. D., Vagner, L., Janoskova, K., Grecu, I., Grecu, G. (2019). Big Data-driven Algorithmic Decision-Making in Selecting and Managing Employees: Advanced Predictive Analytics, Workforce Metrics, and Digital Innovations for Enhancing Organizational Human Capital. Psychosociological Issues in Human Resource Management, 7(2), 49-54.

6. Wyoma, W., Podhorska, I., Siekelova, A. (2019). Does the Growth of Artificial Intelligence and Automation Shape Talent Attraction and Retention?, Psychosociological Issues in Human Resource Management, 7(1), 30-35.

7. Clarke, H., Sulsky, L. (2019). The Impact of Gender Stereotypes on the Appraisal of Civic Virtue Performance. Journal of Research in Gender Studies, 9(2), 25-43.

8. Martins, L. L. (2020). Strategic Diversity Leadership: The Role of Senior Leaders in Delivering the Diversity Dividend. Journal of Management, 46(7), 1191-1204.

9. Babalola, M. T., Stouten, J., Euwema, M. C., Ovadje, F. (2018). The relation between ethical leadership and workplace conflicts: The mediating role of employee resolution efficacy. Journal of Management, 44(5), 2037-2063.

10. Cilliers, J., Fleisch, B., Prinsloo, C., Taylor, S. (2020). How to improve teaching practice? An experimental comparison of centralized training and in-classroom coaching. Journal of Human Resources, 55(3), 926-962.

11. Morgan, M., Baert, P. (2015). Conflict in the Academy: A Study in the Sociology of Intellectuals. Springer.

12. Allcock, D., Filatotchev, I. (2010). Executive incentive schemes in initial public offerings: The effects of multiple-agency conflicts and corporate governance. Journal of Management, 36(3), 663-686.

13. Lamberti, A. P., Richards, A. R. (2019). Communication and Conflict Studies: Disciplinary Connections, Research Directions. Springer Nature.

14. Reuver, M.D., Bouwman, H., Haaker, T. (2015). Business Model Roadmapping: A Practical Approach to Come from an Existing To A Desired Business Model. International Journal of Innovation Management, 17(1), Article Number 1340006.

15. Grznar, P., Gregor, M., Mozol, S., Krajcovic, M., Dulina, L., Gaso, M., Major, M. (2019). A System to Determine the Optimal Work-in-Progress Inventory Stored in Interoperation Manufacturing Buffers. Sustainability. 11 (14), Article Number 3949.

16. Fusko, M., Buckova, M., Gaso, M., Krajcovic, M., Dulina, L., Skokan, R. (2019). Concept of Long-Term Sustainable Intralogistics in Plastic Recycling Factory. Sustainability. 11(23), Article Number 6750. 
17. Worobel, R., Capek, J., Kovacova, L., Bubenik, P., Krajcovic, M. (2018). Improving business processes using simulation tools. MM science journal, 2018, 2244-2251.

18. Fusko, M., Rakyta, M., Dulina, L., Sulirova, I., Edl, M. (2018). Digitization in the technical service management system. MM science journal, 2018, 2260-2266.

19. Durica, L., Gregor, M., Vavrik, V., Marschall, M., Grznar, P., Mozol, S. (2019). A Route Planner Using a Delegate Multi-Agent System for a Modular Manufacturing Line: Proof of Concept. Applied sciences-basel. 9 (21), article Number 4515. 